\section{¡Meta cumplida!}

\section{Done!}

\author{
María Carolina Cabrera Schulmeyer ${ }^{1}$
}

$\mathrm{N}$ os propusimos publicar 6 números este año y aquí está el número 6.

Gracias al interés y trabajo de todos los autores y coautores que nos han enviado sus interesantes investigaciones, casos clínicos y revisiones, que cada día aumentan en número y calidad. Es difícil seleccionar de tal forma que la revista esté balanceada en los temas y no siempre es posible respetar el orden de llegada. Esta es la razón por la que unos artículos se publican antes que otros.

He intentado privilegiar los trabajos que tengan que ver con COVID-19, para así compartir experiencias y que, eventualmente, les pueda ser de utilidad durante esta pandemia y que de verdad espero que si no se publicaran ahora, en el futuro estarían obsoletos.

Por esto pido disculpas a algunos autores que sientan que sus aportes han tardado mucho en ser publicados.

A partir de este número voy a empezar a publicar sobre importantes temas en Anestesiología. La idea de estas monografías es leer sobre un tema frecuente y así recordar lo aprendido y reactualizarse en los eventuales avances.

Pienso que, además, esto hará más atractiva la revista para residentes, internos e incluso médicos que se estén preparando para realizar su especialización en Anestesiología.

En este número comenzaremos con anestesia para el cardiópata sometido a cirugía no cardíaca. Es un artículo de revisión muy completo y totalmente actualizado.

En esta revista número 6 se incluyeron temas de mucho interés. Una revisión sobre la utilidad del catéter de LCR como medida protectora de la médula espinal, de muy buena calidad y fácil de seguir y entender.

Desde España nos llegó una interesante colaboración donde nos presentan los eventos adversos de 10 años en anestesia pediátrica, muy honesto mostrar las propias complicaciones.

¿Y si tienen un paro cardíaco en prono? Qué situación más compleja verdad. Aquí va una muy buena revisión de lo que tendrían que realizar.

Y seguimos intentando aprender más sobre este virus que parece que llegó para quedarse... y que es complejo, cambiante. Una excelente revisión sobre falla renal aguda y sobre tromboprofilaxis en COVID-19.

Cada vez aumentan las contribuciones de diferentes países. Recibí un aporte desde el Congo, interesante, de un país que tiene problemáticas diversas y algunas parecidas a las nuestras como es la formación de pregrado. También me ha llegado material desde Egipto, España y de toda América Latina.

Esto ha permitido un crecimiento muy grande de lectores y visitas a nuestra página web lo que ha permitido consolidar la revista como un órgano válido del conocimiento y actualización en Anestesiología.

Me he planteado que esta revista sea cercana a ustedes, los autores pueden tener comunicación directa conmigo y así cambiar un poco el paradigma de ese comité editorial lejano y distante. La idea es que el material se recibe y se corrige para que sea publicado.

Y así seguir creciendo y aportando en su práctica clínica diaria.

¡La Revista Chilena de Anestesia la escribimos entre todos!

Editora Jefe Revista Chilena de Anestesia.

Anestesióloga Universidad de Valparaíso sede Hospital FACH

\title{
ORCID
}

https://orcid.org/0000-0002-6105-5780

Correspondencia:

maria.cabrera@uv.cl 